DOI https://doi.org/10.32782/2305-9389/2020.23.13

UDC 930.85+94(100)

\author{
Doctor of Philosophical Sciences, \\ Associate Professor at the Department of World History and Methodology of Science \\ South Ukrainian National Pedagogical University named after K. D. Ushynsky

\section{MANIFESTATION OF THE UTOPISM \\ OF MILLENNIALIST TEACHING IN THE HISTORY OF THE COUNTRIES OF WESTERN EUROPE OF THE MIDDLE AGES}

Okorokova Vira,

The article is devoted to the consideration of the medieval utopia in the line of millenarian doctrine. According to the logic of the study, the author begins his analysis of the issue by studying the specifics of the perception of time and history by medieval man, as a result proceeds to determine the essence of millenarianism, its characteristics. The peasant uprising in Germany in 1524-1526, led by Thomas Munzer, is considered as an example of the utopianism of millenarian doctrine.

The author draws attention to the fact that utopia in the medieval society of Western Europe did not have a significant level of manifestation. We are talking about the influence of religion on all spheres of society at that time, which was expressed in the specifics of worldview based on religious canons. Christian culture at this time offered a slightly different interpretation of time and historical process, in contrast to the previous era. The ancient cyclicalism of the historical process was rejected, at the same time declaring its irreversibility, because everything that happens in the New Testament version of time is a series of unique, inimitable phenomena. We are talking about the linear perception of time, its completeness, which is expressed in the eschatological doctrine. Of course, in such conditions, utopia, acting as a product of human consciousness, received a new sphere of formation of its ideal.

In this case, millenarianism became the religious and ideological basis for the formation of the utopian ideal. The ideal world here is the world that will come after the second coming of Christ. In this perspective, the protest character of the millenarian movement of T. Munzer has a pronounced utopian character, because here we see that the purpose of his movement was the need to change the existing social reality and embody the utopian ideal. Aimed at the struggle against the feudal lords, the radical peasant movement was regarded by T. Munzer as a struggle between "good and evil". The ultimate goal of which was to achieve a perfect social status.

Key words: millenarianism, utopia, utopianism, the Middle Ages.

\title{
Окорокова Віра. Прояв утопізму мілленаристського вчення в історії країн Західної Свропи епохи Середньовіччя
}

Стаття присвячена розгляду середньовічної утопї в руслі мілленаристського вчення. Згідно з логікою дослідження, автор починає свій аналіз питання з дослідження специфіки сприйняття часу та історії середньовічною людиною, внаслідок иього переходить до визначення сутності мілленаризму, його характеристик. Як приклад прояву утопізму мілленаристського вчення розглядається селянське повстання в Німеччині 1524-1526 років під проводом Томаса Мюниера.

Автор звертає увагу на ту обставину, щз утопія в середньовічному суспільстві країн Західної Свропи не мала значного рівня прояву. Йдеться про вплив релігії на всі сфери тодішнього суспільства, щзо виразилося у специфіці світосприйняття на основі релігійних канонів. Християнська культура в иееи час пропонувала дещзо іншу інтерпретацію часу та історичного процесу, на відміну від попередньої епохи. Античний ичиклізм історичного процесу було відхилено, проголошено одночасно його незворотність, бо все, щчо відбувається в новозавітній версії часу, є низкою явищ унікальних, неповторних. Йдеться про лінійне сприйняття часу, його завершеність, щзо виражається в есхатологічному вченні. Звісно, в таких умовах утопія, виступаючи породженням людської свідомості, отримала нову сферу формування свого ідеалу.

У иьому випадку мілленаризм став релігійною та ідеологічною основою формування утопічного ідеалу. Ідеальним тут виступає світ, який настане після другого пришестя Христа. У изьму ракурсі протестний характер мілленаристкього руху Т. Мюнцера має явно виражений характер утопізму, адже тут ми бачимо, щзо метою його руху стала вже необхідність змінити сочіальну дійсність і втілити утопічний ідеал. Спрямований на боротьбу з феодалами, радикально налаштований селянський рух розглядався Т. Мюниером як боротьба «добра зі злом», кінцевою метою якого мало стати досягнення досконалого соціального стану.

Ключові слова: мілленаризм, утопія, утопізм, епоха Середньовіччя.

Formulation of the problem. The history of utopian thought reveals a kind of history of human culture, pointing out the peculiarities of the perception of the world, the social ideal, and prognostic expectations. Speaking about utopia, we thereby touch upon a huge layer of a person's being of a particular era. Like any other cultural phenomenon, utopia has its own evolution, i.e. periodicity in the process of the history of society, 
civilization. In each era, we can see elements of utopian thought, and only the level of its manifestation indicates the features of the socio-political and spiritual life of a person and society as a whole. We can say that utopia is subject to historical cyclism, a period of decline is followed by a period of rise of utopia, and vice versa. This can be seen especially clearly in the history of utopian thought in Western European culture.

In this sense, the medieval era is of particular interest, since it acts as a period of temporary lull in utopian thought. Due to the domination of the religious worldview, worldview, human consciousness cognized the world around it in accordance with the prescriptive canons. Any departure from them, distortion was perceived as heresy, etc. However, this does not mean that utopia ceases to exist at this time, it passes into the form of a popular utopia and Christian or religious. Studying this issue, E. Balushkina, O. Kuznetsov, M. Mukhametkhanova, T. Olson, N. Frye draw attention to the connection between millenarian doctrine and utopia. We can say that we are talking about the formation of utopia based on the theology of history.

So, E. Balushkina identifies two characteristics of medieval millenarianism, which became the basis for the formation of utopia: the idea of equality is the idea of universal prosperity and prosperity, when the benefits are distributed by God himself and without taking into account the social or financial situation p. 243. The category of justice - the millenarian idea of the millennial kingdom of God on Earth implies the extension of the highest justice to all living [1, c. 244].

O. Kuznetsov, comparing utopia and millenarian doctrine of this time, draws attention to their generic similarity - communion with eternity, the existence of a kind of parallel world, a world of dreams, desires, fulfillment of hopes. However, the scientist continues, in utopianism, in addition to this, there is also a thirst for a breakthrough, as an acute experience of a breakdown of existence, taken from the perspective of the due [4, c. 41].

M. Mukhametkhanova generally speaks of the existence of a religious utopia at this time, since millenarianism quite definitely presupposes the earthly reign of Jesus Christ with the onset of an ideal state of society [5].

The aim of the study. In connection with the above, the aim of our study is to explicate the manifestation of utopianism in the millenarian teachings of the Middle Ages.

Presenting main material. First of all, it should be noted that, as is known, in the Middle Ages, religious consciousness became the basis of world outlook. The Church and Christian ideology, overcoming the disunity of the innumerable temporal scales of local and family groups, imposed their understanding of time on them, subordinating earthly time to heavenly "eternity". Time as a problem, as a pure concept, existed at that period only for theologians and philosophers, while the rest of society experienced it mainly in the forms of natural and generic time, influenced by the Christian concept of time, which gave rise to a special attitude to history, a specific medieval historicism. connecting the mortal human unit with the whole - with the human race and giving life a new meaning [3, c. 125].

According to A. Gurevich, time in medieval society is slowly flowing, unhurried, for a long time. He is not protected. The past, as it were, constantly returns and thus gives solidity, weight, and lasting character to the present. Christianity has brought a significant new moment in this respect. Along with the revival of the biblical past through prayer and ordinances, it also created perspective. The connection of times opened by Christianity gave history a teleological, finalistic meaning. The present in this regard did not acquire an independent meaning: being included in the world-historical drama, it was at the same time, as it were, devalued by the expectation of the impending Last Judgment and was colored by a complex set of feelings the hope of redemption and the fear of retribution for sins [3, c. 125-126].

Continuing the study of time and history in the perception of medieval man, the scientist notes that in the Middle Ages, the church kept social time under its control, the clergy established and directed the entire course of time of feudal society, regulating its rhythms. Any attempts to get out of the church's time control were strictly suppressed: the church forbade work on holidays, and the observance of religious prohibitions seemed to it more essential than obtaining an additional mass of surplus product that could be produced on days declared forbidden for labor and which took more thirds of the time of the year; the church determined the composition of food that could be taken in certain periods of time, and strictly punished for breaking the fast; she even interfered with sex life, prescribing when sexual intercourse is permissible and when it is sinful. With the help of funeral prayers and masses, the church could shorten the time of the afterlife torture of souls and, therefore, exercised control not only over the time of the living, but also over the time of the dead. As a result of such an all-encompassing control over time, complete subordination of man to the dominant social and ideological system was achieved. The time of an individual was not his individual time; it did not belong to him, but to a higher power standing above him. Therefore, resistance to the ruling class in the Middle Ages resulted in a protest against its control over time: eschatological sects, predicting the impending end of the world and calling for repentance and renunciation of the blessings of earthly life, questioned the value of church time. 
The aforementioned largely explains why it was precisely in the millennial doctrine that utopian thought found its way out in the Middle Ages. The term "millenarianism", which is most prevalent in the Protestant world, is the Latin translation of the Greek "chiliasm", a term of Eastern Patristics. In general, chiliasm is a given of chiliasticism at the level of ideological doctrines, in which an explanation is given as to where this sought-for "kingdom of freedom" is located, when it will come and how to get there [4]. Millenarianism, or chiliasm, means the hopes and aspirations of believers associated with the Second Coming of the Savior and His millennial kingdom. According to A. Grigorenko's definition, millenarianism is a teaching about the coming millennial kingdom of God and the second coming of the Savior - the Messiah [2].

During the formation of early Christianity, millenarian hopes and expectations became an important part of the new denomination and in subsequent times run like a red thread throughout the history of the church, revealing their existence with special force during the Reformation in Western Europe in the 16th century. More than once, fierce disputes flared up between adherents of millenarian expectations of the imminent onset of the earthly millennial kingdom of Christ and their opponents, who deny such expectations as disagreeing with the spirit and essence of Christian doctrine. These disputes were often resolved by appealing to the strength and authority of the state by opponents of millenarianism for support [2].

The chiliastic mentality, along with the eschatological and apocalyptic, belongs to the deepest layers of the world outlook. Man is an imperfect being and realizing his imperfection, having an idea of perfection and striving for it. Man is the only being who criticizes the existing situation from the standpoint of the imperative, imperfect - from the standpoint of the perfect, the ultimate - from the standpoint of the beyond. Chiliastic views set two planes of vision of events taking place in history - this-worldly and other-worldly. If the main problematics of eschatology can be called the doctrine of the limitation of human existence and, accordingly, the doctrine of the beyond and the connection between the ultimate and the beyond, apocalypticism is the doctrine of the worldwide opposition of the forces of good and evil, of the relationship of natural and supernatural forces in this opposition, then the main chiliastic problematic - this is a teaching about the otherworldly, different, perfect world, about the connection between two worlds, two states - the state of pain, sin, death and a blissful state. In a secular form, close to everyday life and mass movements, chiliastic ideas exist in two forms millenarianism and utopianism, common to which are the archetypal image of the Kingdom of God on earth, the ideals of freedom, equality, justice, reward for the righteous and finding what is sought by strengthening earthly hope $[4$, c. 38].

A. Gurevich points to the need to consider it as an integral part of the Middle Ages, a form in which the social aspirations of the oppressed and disadvantaged were molded. Sometimes the expectation of the end of the world developed into mass panic states, into an epidemic of repentance and self-flagellation. Chiliasm was a peculiar form of attitude towards the future, a vital aspect of the concept of time in a number of social groups. The very course of history was interpreted by millenaries contrary to the official church doctrine, arguing that the day of the Last Judgment would be preceded by the millennial Kingdom of Christ on earth, denying all feudal and church institutions, property and social order. The apocalyptic expectation of an early "end of time" symbolized the sectarian hostility to the orthodox concept of time. The danger of eschatological sects for the ruling church lay in the fact that, predicting and rushing the immediate approach of the end of the world, they deprived the inner justification of the earthly order proclaimed by the church to be Godestablished [3, c. 127].

The order of key quasi-historical events at the end of history as a whole coincides with the order of mankind's earthly journey from expulsion from the Garden of Eden to settlement in holy Jerusalem. The Millennium is a quasi-historical time, a projection of historical time beyond its limits, a kind of second plan of messianic time from the first to the second coming of Jesus Christ. The duality of social being - being and what is due, realities and the ideal, the natural laws of human society and divine institutions - is given in the image of the millennium, in this being localized in ahistorical space and time, with utmost clarity [4, c. 39]. The heavenly testimony of Enoch and Elijah, the light of the beginning and end times, the suprahistoric sojourn of the millennium characterize the presence of the eternal in the transitory, the extrahistorical in the historical, providential in the eventual.

Thus, we see that the religious outlook, the awareness of one's place in the world, the eschatological doctrine, in the end the millenarian foresight of the future as preparation for the second coming, etc., in fact, formed a certain utopian ideal that meets the interests of the then man. In the secular version of millenarianism, the Kingdom of God becomes a Utopia, a description of the perfect form of human community, or "a place that does not exist".

In this sense, O. Kuznetsov focuses on the fact that if you take the images of the blessed land, then for utopianism the millennium is rather a lost island that must be found; a mountain to which, in many respects, by 
chance, the waves will beat the ship in distress; the promised land in the midst of a sea of adversity, hardship and suffering; in the everyday sense - an unknown country that exists somewhere, but not here (Western European version: the country of Cockain - a place of joy and doing nothing), an oasis in the desert, like a mirage. The archetypal intellectual construction is Plato's utopia, a well-oiled, proportionate world. In turn, Plato's utopia is rooted in ancient mythological ideas about the earth as a middle world surrounded by world waters, and as a mesocosm - a sphere of orderliness amid chaos, a sphere of action of light (law, however, justice) $[4$, c. 41$]$.

The utopianism of the millenarian doctrine is especially vividly manifested in the example of the peasant uprising in Germany in 1524-1526 under the leadership of Thomas Munzer. Interestingly, as F. Manuel and Fr. Manuel's millenarian faith has often accompanied popular uprisings. Participants in popular uprisings of artisans and peasants, who harbored hostility to the church hierarchy, combined with a deep antagonism of the poor against the rich gentlemen and burghers, found in the Bible a model of a society that should replace the hated order [7]. The rationalistic urban utopias of the Greek philosophers were rejected, the ancient motifs of the folklore utopias of the Cocaine country were drowned out by the paradisiacal images inspired by the Bible and prophecies. Fourteenth-century English Lollards, led by John Ball, found in the Gospel a justification for social and political protest: Holy Scripture gave them a sanctified image of the world as it should be. The Hussites of Bohemia dreamed of a patriarchal order, of rulers like the prophets of the Old Testament. Fantasies were rooted even deeper, to the gardens of Eden, to the naturalness and simplicity of the first man, to truth in its purest form. Calls to spiritual truth and bodily nudity were combined in the vision of the new birth. The Antichrist and his powers are identified with the rich, ruling, orthodox clergy; the day of the bloody catastrophe is known in advance, after which a good emperor, or a mystical leader, or Christ himself will reign on earth.

And Müntzer called upon believers to appear naked before God, freed from everything created. His doctrine of inner illumination opened up new possibilities for new social interpretations of the gospel. The prophecy of Daniel that the power of heaven will be given to the people of the saints of the Most High, Munzer interpreted as the consecration of the power of ordinary people. Although he revered the abbey of Joachim of Flora, in his view the kingdom of God did not belong to the holy monastic order, but to ordinary people, peasants who rebelled against their masters. Therefore, it was the common people who became the backbone of his movement, capable of suffering in the name of God and making self-sacrifice for the sake of fulfilling His goals. Münzer believed that through the transfer of judgment and power to the brotherhood of the poor, their inner improvement and enlightenment, one could achieve heavenly life. Simple people, common people were bearers of Divine justice, because they understood the meaning of the kingdom of God better than any scientist. In Münzer's "social" interpretation of the prophets of the Old Testament, the peasants are exalted above the mighty of this world. Munzer put the common people above the "depraved" gentlemen.

T. Munzer tried to unite the peasants in the brotherhood of the kingdom of God - Christliche Vereinigung Christian Union, emphasizing that through the transfer of court and power to the brotherhood of the poor, their inner improvement and understanding can achieve heavenly life. In his view, the common people, the common people, were the bearers of God's justice, because they understood the meaning of the kingdom of God better than any scientist or theologian. In Munzer's "social interpretation" of the Old Testament prophets, the peasants are elevated above the strongest of this world. The gospel carries the truth of new life, its meaning and plan are not equally available to all Christians. The common man is closer to understanding the Gospel than to know, unable to comprehend life in his luxurious existence [8, c. 336].

It was in the movement of Münzer that the millenarian doctrine of the earthly paradise acquires an estate character, and most importantly becomes revolutionary. Here, not just utopia is very obvious, but utopianism, as the highest measure of manifestation of utopia, which is expressed in an attempt to introduce the utopian ideal into socio-historical reality. The radicalism with which T. Munzer spoke, directing people to oppose their masters in order to bring an ideal social position closer, only once again proves the utopianism of his views.

Naturally, this movement, led by T. Münzer, was defeated. His numerous disorderly army, armed with pikes and sticks against the cavalry and artillery of their oppressors, was utterly defeated at Frankenhausen, and the hiding leader was found and taken to the castle of Prince Ernst von Mansfeld. But the very fact of this millenarian movement, revolutionary in nature, became an example of the manifestation of utopianism. As noted in this regard, F. Manuel and Fr. Manuel, in a radical Christian utopia, it is equally difficult to enter the kingdom of God on earth and in heaven. There is no place here for the compromises of the humanist Republic of Mora, nor for the imperfection of its inhabitants. Muntzer realized himself as Daniel, who came on the eve of the Day of Judgment to lead those who, having denied the sins of this world, with their whole being wants to be imbued with the fear of God and prepare for the Apocalypse. 
M. Mukhametkhanova, studying religious utopia, points out that in many utopias there are messianic and eschatological motives, and many utopian projects include religion as an obligatory moment of the ideal social structure and offer their own version of the cult. Religious consciousness is not homogeneous, and in life the utopian type of consciousness can manifest itself, including in a religious form. Religion can be both a source that feeds utopias and their limiter, a way of demystifying all human projects. The scientist agrees with the opinion of other scientists that utopia can be called a regression of religious consciousness, a kind of neo-paganism. However, at the same time, he argues that the process of replacing religious utopias with secular ones is not linear, it is cyclical: the change occurs due to the action of the law of the irony of history not a single utopia can be fully embodied, not one can give a person and society absolute comfort and peace. A person continues to be dissatisfied with the world around him and tries to change it, producing utopias [6, c. 216-217].

Conclusions. Thus, the analysis of this problem shows that medieval utopia became a product of religious teachings. It is interesting that millenarianism became the basis of the protest movement, its ideological design, as it gave hope to the masses for the possibility of an ideal state of society after the second coming. In fact, T. Müntzer's movement became an example of utopianism, since he not only substantiated the goal and methods of struggle (mainly revolutionary), but also gave hope to the masses of the people for the possibility of achieving this "blissful" state as a result of the struggle "against evil". In this case, another feature appears that connects utopia with millenarianism at this time - the dichotomy of the world into real / surreal. On the basis of criticism of the existing social reality, utopia creates an alternative to the present, offers its own, more perfect version. In this case, we are talking about a utopian ideal, the basis of which is the eschatological doctrine of the end of the world, the victory of good over evil, etc.

1. Балушкина Е.В. От средневекового милленаризма к революционной утопии. Вестник РГГУ. 2013. № 13(114). C. 235-247.

2. Григоренко А.Ю. Эсхатология, милленаризм, адвентизм: история и современность. URL: https://azbyka.ru/otechnik/ sekty/eshatologija-millenarizm-adventizm-istorija-i-sovremennost/2_1

3. Гуревич А.Я. Избранные труды. Средневековый мир. Санкт-Петербург : Изд-во С.-Петерб. ун-та, 2007.560 с

4. Кузнецов О.В. Милленаризм и утопизм: хилиастическая идея приобщения к вечности. Вестник КГУ. 2006. № 3. С. 38-42.

5. Мухаметханова М.Р. Религиозная утопия как феномен и понятие. Вестник ЛГУ им. А.С. Пушкина. 2013. С. $207-217$.

6. Mumford L. The story of utopias. New York: The Viking press, 1971. 315 p.

7. Мэнюэль Ф.Э. и Мэнюэль Фр. П. Утопическое мышление в западном мире. Москва : Прогресс, 1991. С. $21-41$. URL: http://chalikova.ru/menyuel-utopicheskoe-myishlenie-v-zapadnom-mire.html

8. Окорокова В.В. Окремість середньовічної утопії як одного з «темних періодів» в історії утопічної думки. Гілея: Науковий вісник. 2012. Випуск 56 (№ 1). С. 333-338.

9. Olson T. Millenialism, utopianism, and progress. Toronto : The University of Toronto press, 1982. $332 \mathrm{p}$.

10. Frye N. Anatomy of Criticism: Four Essays. New York, 1969. 383 p. 